\title{
Estradiol-Induced Potentiation of Dopamine Release in Dorsal Striatum Following Amphetamine Administration Requires Estradiol Receptors and mGlu5
}

\author{
Zhimin Song, ${ }^{1}$ Hongyan Yang, ${ }^{3}$ Elizabeth M. Peckham, ${ }^{4}$ and Jill B. Becker ${ }^{1,2}$
}

https://doi.org/10.1523/ENEURO.0446-18.2019

${ }^{1}$ Molecular and Behavioral Neuroscience Institute, ${ }^{2}$ Department of Psychology, University of Michigan, Ann Arbor, Michigan 48109, ${ }^{3}$ Department of Psychiatry and Biobehavioral Science, Semel Institute for Neuroscience and Human Behavior, and Hatos Center for Neuropharmacology, University of California, Los Angeles, California 90095, and ${ }^{4}$ Department of Biology, Concordia University, Ann Arbor, Michigan 48105

\begin{abstract}
Estradiol potentiates behavioral sensitization to cocaine as well as self-administration of cocaine and other drugs of abuse in female rodents. Furthermore, stimulated dopamine (DA) in the dorsolateral striatum (DLS) is rapidly enhanced by estradiol, and it is hypothesized that this enhanced DA release mediates the more rapid escalation of drug taking seen in females, compared with males. The mechanisms mediating the effect of estradiol to enhance stimulated DA release were investigated in this study. Using in vivo microdialysis and high performance liquid chromatography coupled with electrochemical detection, we first examined the effect of estradiol on amphetamineinduced DA increase in the DLS of ovariectomized rats. We then tested whether the potentiation of this DA increase could be blocked by the estradiol receptor antagonist, ICI 182,780 (ICI), or an antagonist to the metabotropic glutamate receptor subtype 5 (mGlu5), 2-methyl-6-(phenylethynyl)pyridine (MPEP). There is evidence that estradiol receptors collaborate with mGlu5 within caveoli in DLS and mGlu5 is hypothesized to mediate many of the effects of estradiol in the addiction processes in females. Our data show that estradiol enhances the DA response to amphetamine. Either ICl or MPEP prevented the effect of estradiol to enhance DA release. Importantly, our results also showed that neither $\mathrm{ICl}$ or MPEP alone is able to influence the DA response to amphetamine when estradiol is not administrated, suggesting that $\mathrm{ICl}$ and MPEP act via estradiol receptors. Together, our findings demonstrate that estradiol potentiates amphetamine-stimulated DA release in the DLS and this effect requires both estradiol receptors and mGlu5.
\end{abstract}

Key words: addiction; drug abuse; gonadal hormones; reward; sex difference

\section{Significance Statement}

The present study provides important information on the neurobiological mechanisms underlying the exacerbating effects of E2 on addictive behavior by showing blockage of E2 receptors or mGlu5 reduces E2-induced potentiation of DA release in the rat striatum following by amphetamine injections. Our data suggest that targeting E2 receptors or mGluRs could have treatment potentials for E2-related disorders in areas such as, but not limited to, drug addiction.

Received November 12, 2018; accepted January 21, 2019; First published January 28, 2019

The authors declare no competing financial interests.
Author contributions: Z.S., H.Y., and J.B.B. designed research; Z.S., H.Y., and E.M.P. performed research; Z.S. analyzed data; Z.S. and H.Y. wrote the paper. 


\section{Introduction}

Women are more susceptible to drugs of abuse than men. They escalate faster from initial use to addiction, take more drugs when addicted, and have a harder time staying abstinent (Bobzean et al., 2014). This is mirrored in animal models, female rats acquire drug self-administration at a faster rate, are more motivated to take drugs, and respond stronger to drug cues during reinstatement (Becker 2016; Song et al., 2018).

It is suggested that these sex differences are regulated at least in part by estradiol (E2). Indeed, there is considerable evidence that shows the potentiating roles of E2 in cocaine self-administration, cocaine behavioral sensitization, and dopamine (DA) signaling in the nucleus accumbens (NAc) following cocaine administration ( $\mathrm{Hu}$ and Becker, 2008). Despite this mounting evidence, how E2 enhances stimulated DA release or addiction-related behaviors are less well understood.

Many of the E2 effects involve intracellular estrogen receptors $\mathrm{ER} \alpha \mathrm{s}$ and $\mathrm{ER} \beta \mathrm{s}$ (Foster 2012; Borrow and Handa, 2017). Recently, E2 was also shown to bind to a membrane G-protein-coupled receptor GPER-1 (Long et al., 2014). Depending on the types/locations of the receptors, the effects of E2 can range from minutes (nongenomic effects) to days (genomic effects; Ervin et al., 2015). In dorsal striatum (DS), a region that is critical for habitual drug taking behavior, E2 modulates behavior by acting on GABA medium spiny neurons (MSNs; Mermelstein et al., 1996) and by altering DA transmission indirectly through a presynaptic mechanism (Xiao and Becker, 1998; Schultz et al., 2009).

In the present study by using in vivo microdialysis and high-performance liquid chromatography (HPLC) coupled with electrochemical detection (ECD), we first examined effects of E2 on amphetamine (AMPH)-induced DA elevation in the striatum of female rats. We then tested whether the observed potentiated DA elevation could be blocked by an E2 receptor antagonist $\mathrm{ICl} 182780$ (ICl) or an antagonist to the metabotropic glutamate receptor subtype 5 (mGlu5), 2-methyl-6-(phenylethynyl)pyridine (MPEP) in the striatum as there is evidence that mGlu5 is required for many of the effects of E2 in addiction processes (Martinez et al., 2014, 2016).

\section{Materials and Methods}

\section{Animals}

Female Sprague-Dawley rats (weighting 200-225 g at the beginning of each experiment; were obtained from Harlan Laboratories or Charles River Laboratories) and

This work was supported by NIDA DA039952 to J.B.B. We thank Brandon Luma for logistic and technical help during the experiment.

Z. Song's present address: Department of Psychology, Emory University, Atlanta, GA 30322.

Correspondence should be addressed to Jill B. Becker at jbbecker@umich.edu.

https://doi.org/10.1523/ENEURO.0446-18.2019

Copyright (C) 2019 Song et al.

This is an open-access article distributed under the terms of the Creative Commons Attribution 4.0 International license, which permits unrestricted use, distribution and reproduction in any medium provided that the original work is properly attributed. housed in groups of two or three per cage before cannula implantation and singly housed after cannula implantation, under a 14/10 $\mathrm{h}$ light/dark cycle. The rats were housed in a room maintained at a constant temperature of $20-21^{\circ} \mathrm{C}$, with phytoestrogen-free rodent chow (2014 Teklad Global, 14\% protein rodent maintenance diet, Harlan rat chow; Harlan Teklad) and water available ad libitum. All procedures were performed according to the protocol approved by the Committee for Use and Care of Animals at the University and were in accordance with the NIH Guide for the Care and Use of Laboratory Animals.

\section{Ovariectomy}

Approximately 1 week after arrival, all animals underwent bilateral ovariectomy (OVX). The OVXs were conducted using a dorsal approach under anesthesia of $\sim 2 \%$ isoflurane/oxygen. The skin was opened with an incision $\sim 1 \mathrm{~cm}$ long along the midline just below the ribs, and a small incision $\sim 0.5 \mathrm{~cm}$ long was made through the muscle 1.5-2 cm lateral to the midline. The ovary was externalized with blunt forceps, and the tissue between the ovary and uterus was clamped with a hemostat. The ovary was removed, and the hemostat remained in place until there was no bleeding before being released. The uterus with associated tissue was then returned to the abdomen. The procedure was repeated on the other side, and the wound was closed with $9 \mathrm{~mm}$ wound clips. The wound clips were removed after $14 \mathrm{~d}$ of OVX. After $7 \mathrm{~d}$ of recovery, all animals underwent vaginal lavage testing daily for 10 consecutive days to confirm cessation of cycling.

\section{Cannula implantation}

Two to 3 weeks after OVX, all rats received buprenorphine (0.01 mg/kg, s.c.) or carprofen (5 mg/kg, s.c.) 30-60 min ahead of the cannula implantation surgery. During the surgery, all rats were anesthetized with ketamine (60 mg/kg, i.p.) and dexmedetomidine $(0.3 \mathrm{mg} / \mathrm{kg}$, i.p.). Guide cannulae (matching for CMA/11 probes, CMA Microdialysis, or MAB 6 probes, SciPro; 4 mm membrane length) were inserted through the skull aimed at the striatum (AP +0.20 mm, ML $\pm 3.00 \mathrm{~mm}$, DV -1.50 mm) using standard stereotaxic techniques. The cannulae were held in place with acrylic polymer (Lang), which was secured to the brain with three to four stainless steel jewelry screws (Small Parts). A solid stylet was placed in each cannula when not in use, to keep the cannula patent. Animals were allowed to recover for at least $5 \mathrm{~d}$ before microdialysis. Starting $1 \mathrm{~d}$ after the surgery (both cannula implantation and OVX), rats were administered with carprofen (5 mg/ $\mathrm{kg}$, s.c.) daily for 3 consecutive days and triple antibiotic was given when necessary on observation. All rats were observed at least once daily for 10 consecutive days to ensure their recovery.

\section{Preparation for microdialysis}

Animals were anesthetized with $3 \%$ isoflurane and maintained with $2 \%$ isoflurane during the procedure of removing the stylet and inserting a microdialysis probe into the brain through the guide cannula. Probes were placed into the brain 12-18 $\mathrm{h}$ in advance of the testing to allow sufficient time for the injury-related release associ- 


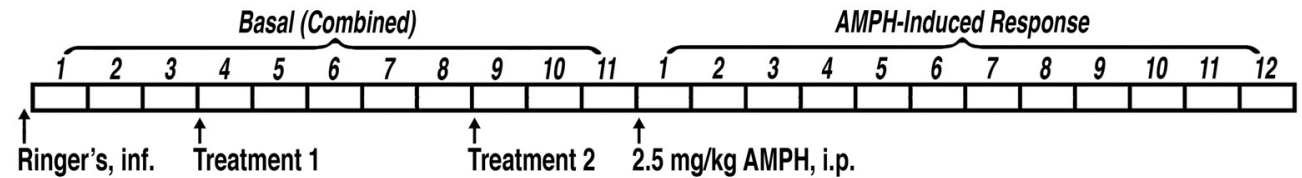

\begin{tabular}{cccc} 
Exp 1 & Treatment 1 & Treatment 2 & Group Size \\
\hline Control I* & Not Apply & $0.1 \mathrm{~mL}$ Peanut Oil, s.c. & $\mathrm{n}=6$ \\
Control II* & $0.02 \%$ EtOH in Ringer's, inf. & $1 \mathrm{~mL} / \mathrm{kg}$ Saline, i.p. & $\mathrm{n}=7$ \\
EB & Not Apply & $5 \mu \mathrm{g} \mathrm{EB} \mathrm{in} \mathrm{0.1} \mathrm{mL} \mathrm{Peanut} \mathrm{Oil,} \mathrm{s.c.}$ & $\mathrm{n}=7$ \\
E2 & $1 \mathrm{ng} / \mathrm{mL} \mathrm{E2} \mathrm{in} 0.02 \%$ EtOH in Ringer's, inf. & $1 \mathrm{~mL} / \mathrm{kg}$ Saline, i.p. & $\mathrm{n}=8$ \\
\hline *
\end{tabular}

\begin{tabular}{|c|c|c|c|}
\hline Exp 2 & Treatment 1 & Treatment 2 & Group Size \\
\hline EB & $0.1 \%$ EtOH in Ringer's, inf. & $5 \mu \mathrm{g}$ EB in $0.1 \mathrm{~mL}$ Peanut Oil, s.c. & $n=8$ \\
\hline $\mathrm{ICl}+\mathrm{EB}$ & $2.32 \mu \mathrm{g} / \mathrm{mL} \mathrm{ICI}$ in $0.1 \% \mathrm{EtOH}$ in Ringer's, inf. & $5 \mu \mathrm{g} \mathrm{EB}$ in $0.1 \mathrm{~mL}$ Peanut Oil, s.c. & $n=9$ \\
\hline Exp 3 & Treatment 1 & Treatment 2 & Group Size \\
\hline E2 & $1 \mathrm{ng} / \mathrm{mL}$ E2 in $0.02 \%$ EtOH in Ringer's, inf. & $1 \mathrm{~mL} / \mathrm{kg}$ Saline, i.p. & $n=9$ \\
\hline E2+MPEP & $1 \mathrm{ng} / \mathrm{mL}$ E2 in $0.02 \%$ EtOH in Ringer's, inf. & 10 mg/kg MPEP in Saline @ $1 \mathrm{~mL} / \mathrm{kg}$, i.p. & $n=9$ \\
\hline Exp 4 & Treatment 1 & Treatment 2 & Group Size \\
\hline Control I* & $1 \mathrm{~mL} / \mathrm{kg}$ Saline, i.p. & $0.1 \mathrm{~mL}$ Peanut Oil, s.c. & $n=4$ \\
\hline Control II * & $0.1 \% \mathrm{EtOH}$ in Ringer's, inf. & $0.1 \mathrm{~mL}$ Peanut Oil, s.c. & $n=4$ \\
\hline MPEP & 10 mg/kg MPEP in Saline @ 1 mL/kg, i.p. & $0.1 \mathrm{~mL}$ Peanut Oil, s.c. & $n=6$ \\
\hline $\mathrm{ICl}$ & $2.32 \mu \mathrm{g} / \mathrm{mL} \mathrm{ICl}$ in $0.1 \% \mathrm{EtOH}$ in Ringer's, inf. & $0.1 \mathrm{~mL}$ Peanut Oil, s.c. & $\mathrm{n}=7$ \\
\hline
\end{tabular}

Figure 1 Schematic diagram of all the treatments in each experiment.

ated with probe implantation to subside. Animals were placed in the test chamber $(31 \times 25 \times 25 \mathrm{~cm})$ with continuous white noise. The microdialysis probes were attached to syringes mounted on the syringe pump, and a Ringer's solution (in mM: $145 \mathrm{NaCl}, 2.7 \mathrm{KCl}, 1 \mathrm{MgSO}_{4}, 1.2$ $\mathrm{CaCl}_{2}, 1.55 \mathrm{Na}_{2} \mathrm{HPO}_{4}, 0.445 \mathrm{NaH}_{2} \mathrm{PO}_{4}, \mathrm{pH} 7.3$ at RT) was continuously pumped through the probe at $1.5 \mu \mathrm{l} / \mathrm{min}$ during the first 30-60 min after probe insertion. Then the pumping speed was reduced to $0.3 \mu \mathrm{l} / \mathrm{min}$ until the next day. To prevent the microdialysis probe, which was secured to the animals' head, from being subjected to the torque created during the movement of animal, the rats was fitted with a custom-made harness, and the harness was attached to a swivel (liquid commutator 375/22 or $375 / \mathrm{D} / 22$, Instech Laboratories) by a flexible stainless steel cable. Rats were left overnight in the testing chamber with food and water ad libitum.

\section{Microdialysis}

Sample collection was initiated the next morning, and all samples were collected in the light phase during 08: 00-12:30. All dialysates were briefly stored on ice in the dark, and then manually injected into the HPLC-ECD system for measuring DA concentration in dialysates during 08:00-15:00 of the same day. Dialysate was collected into vials mounted just above the harness assembly. Drugs and hormones of interest were administered systemically (i.p. or s.c.) or intrastriatally via the microdialysis probe (reverse dialysis). For delivering $\mathrm{E} 2, \mathrm{ICl}$, or MPEP via reverse dialysis method, drugs were first dissolved in pure UPS grade ethanol as $1000 \times$ (or above) stock solution; then, at use, they were further freshly diluted in Ringer's solution and manually filtered via $0.2 \mu \mathrm{m}$ syringe filters. With reverse dialysis, the drug of interest passes through the membrane of a microdialysis probe and diffuses into the striatum down a concentration gradient. Based on the in vitro results, we estimate that the effi- ciency of drug delivery with infusion method is $3-10 \%$ (data not shown). Thus, the effective concentration in the brain is considerably lower than the concentration in the probe. Thirty-sixty minutes before the first sample collection, the pumping speed was increased to $1.5 \mu \mathrm{l} / \mathrm{min}$. Each dialysate sample was collected for $10 \mathrm{~min}$. Baseline samples were collected for $30 \mathrm{~min}$. When drugs were delivered via reverse dialysis, five samples were collected after the solutions were changed and the last three samples were used as the new baseline (it took $\sim 20$ min for a new solution to reach equilibrium in the system). All rats in all experiments received an AMPH injection during microdialysis $(2.5 \mathrm{mg} / \mathrm{kg}$ in saline, i.p.) and $10 \mathrm{~min}$ samples were collected for the following $2 \mathrm{~h}$ (12 samples).

\section{Treatment protocols for each experiment before AMPH administration}

Figure 1 shows treatment details during the microdialysis sample collection in each experiment. Briefly, all rats were infused with Ringer's solution for determining baseline DA and then treated with one or two pretreatments before AMPH injections. Specifically, in Experiment 1, rats were randomly assigned to 1 of 4 groups: (1) E2 Group $(n=7)$, rats were infused with Ringer's solution with E2 in it $(1 \mathrm{ng} / \mathrm{ml} \mathrm{E2}$; first dissolved in $100 \%$ ethanol and then diluted in Ringer's solution, ethanol final concentration $0.02 \%$ ); (2) Estradiol benzoate (EB) Group $(n=8)$, rats were treated with a subcutaneous injection of EB $(5 \mu \mathrm{g}$ in $0.1 \mathrm{ml}$ peanut oil); (3-4) Control Groups, rats received either a subcutaneous injection of peanut oil $(0.1 \mathrm{ml}$ per rat; $n=6$ ) or $0.02 \%$ ethanol in Ringer's solution (vehicle for E2; $n=7$ ). Rats that were treated with peanut oil or ethanol in Ringer's solution did not significantly differ from each other and were combined in the analyses. There were two groups in Experiment 2: the ICI Group $(n=9)$ was infused with Ringer's solution with ICl in it $(2.32 \mu \mathrm{g} / \mathrm{ml}$ $\mathrm{ICl}$, which is an equimolar concentration to $\mathrm{E} 21 \mathrm{ng} / \mathrm{ml}$; 


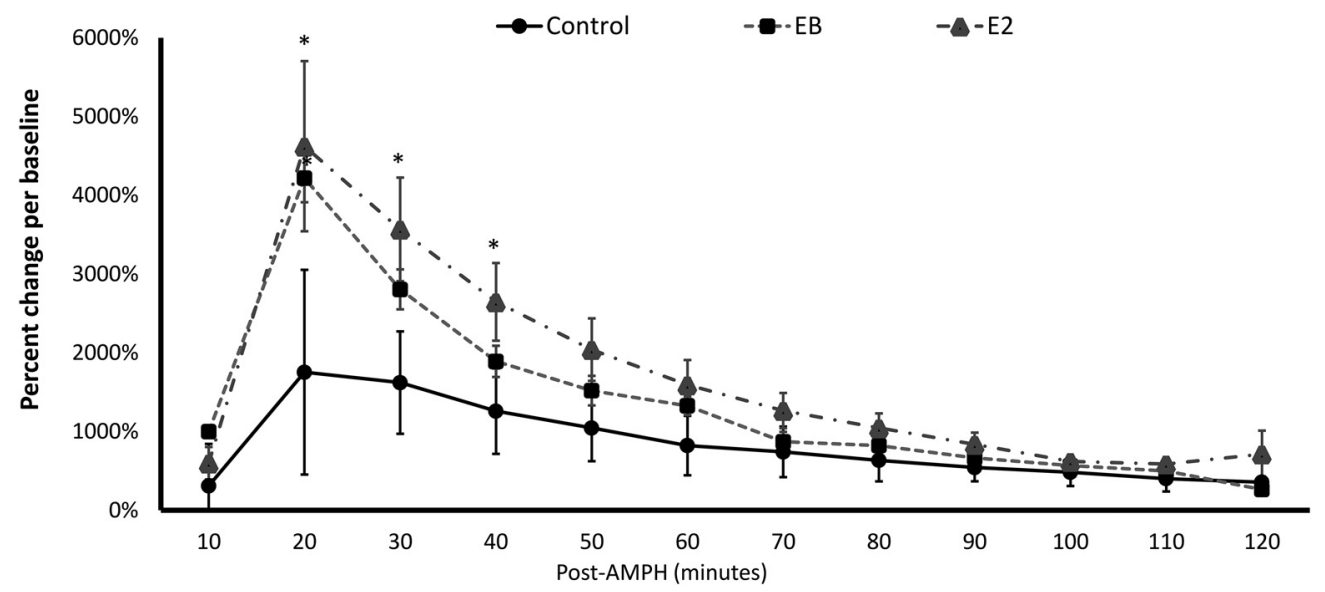

Figure 2 E2 in the DLS or EB, subcutaneously, potentiates DA release following AMPH injections. E2 was dissolved in Ringer's solution and was infused into the DLS via reverse microdialysis. *indicates a significant difference between rats treated with E2 or EB and control rats.

first dissolved in $100 \%$ ethanol and then diluted in Ringer's solution; ethanol final concentration was $0.1 \%)$. The rats then received a subcutaneous EB injection following the ICl treatment. Control Group $(n=8)$ received Ringer's solution with $0.1 \%$ ethanol (vehicle for $\mathrm{ICl}$ ), followed by an EB administration. Experiment 3 also had two groups: E2 + MPEP Rats $(n=9)$ received E2 via reverse dialysis as described above and an intraperitoneal MPEP injection $(10 \mathrm{mg} / \mathrm{kg})$. Control rats $(n=9)$ received E2 via reverse dialysis and an intraperitoneal saline injection. In Experiment 4, rats were assigned into 1 of the 4 groups: $\mathrm{ICI}$ group $(n=7)$, where ICl dissolved in Ringer's solution was administered via reverse dialysis; MPEP group $(n=6)$, where MPEP was injected systemically as above; and two control groups where rat received intraperitoneal saline $(n=4)$ or ICl vehicle $(n=4)$. The two control groups were combined because of similar levels of baseline DA as well as DA concentrations following AMPH injections. All rats were injected with AMPH following these pretreatments and dialysate samples from the DLS were collected every 10 min for 2 consecutive hours.

\section{DA concentration measurement by HPLC}

DA concentration was assayed using a HPLC-ECD system described in (Hu and Becker, 2003). In brief, dialysate samples were separated on an ESA (ESA Biosciences) HPLC column $(\mathrm{HR}-80 \times 3.2,3 \mu \mathrm{m}$ particle size, $80 \mathrm{~mm}$ length) at $40^{\circ} \mathrm{C}$, with a mobile phase consisting of the following (in mM): $75 \mathrm{NaH}_{2} \mathrm{PO}_{4}, 0.2$ EDTA, 1.4 OSA (1octanesul fonic acid sodium salt monohydrate; Fluka, catalog \#74882) and 17\% methanol in HPLC water, $\mathrm{pH}$ 4.7). Flow rate through the column was set to $0.7 \mathrm{ml} / \mathrm{min}$. Dopamine was quantified using a coulometric detector (Coulochem II, ESA) equipped with a high-sensitivity analytical cell containing dual coulometric working electrodes (ESA, model \#5014B). The detector settings were as follows: Detector 1, $-150 \mathrm{mV}$; Detector 2, +100 mV; and guard cell $+300 \mathrm{mV}$. Output from Detector 2 was used for dopamine quantification. The retention time of DA was $\sim 2.5 \mathrm{~min}$.

\section{Histology}

Four to $7 \mathrm{~d}$ following completion of microdialysis, animals received an overdose of anesthesia and were sacrificed. Their brains were prepared for histologic analysis using standard techniques for frozen sections and cresyl violet staining was used to determine the location of the microdialysis probes. Only data from the rats where probes were located inside the DLS are reported here. Two rats were excluded because of the probes going too ventral and six more rats were also excluded because of probe damage or sickness.

\section{Statistical analyses}

We used software SPSS V24 in all data analyses. Data were expressed in mean \pm SEM. The percentage increase from baseline of each rat was used to assess DA response to $\mathrm{AMPH}$ in each $10 \mathrm{~min}$ sample. Baseline was determined by the mean of all samples before AMPH injections because no difference in DA concentrations was found in these samples (data not shown). Mixed-design repeated-measure ANOVA was used to examine treatment effect (e.g., ICl vs vehicle) among groups and the effect of time on DA concentrations within each group. We focused our analyses a priori on the first four samples collected following AMPH to catch patterns of peak DA concentrations in each condition. When significant effects of treatment were found, one-way ANOVA or $t$ test was used to determine whether there was a significant difference in the each of the four samples postAMPH among treatment group(s) and the control group. A priori planned contrast post hoc analysis was used to examine differences among $>2$ groups. Two data points in the first four samples post-AMPH of all rats (from 2 separate rats) were missing because of technical issues and were replaced by the average of the data points right before and after. In cases when assumptions for parametric tests were not met, nonparametric tests (e.g., Mann-Whitney $U$ and Kruskal-Wallis tests) were used.

\section{Results}

Experiment 1: as can be seen in Figure 2, E2 delivered via reverse dialysis directly into the DLS or EB subcuta- 
Table 1 : Comparisons of DA release in response to AMPH among rats with varying pretreatments in Experiments 1-3

\begin{tabular}{|c|c|c|c|c|}
\hline \multicolumn{5}{|c|}{ ANOVA tests comparing rats treated with EB, E2, and Vehicle in Experiment 1} \\
\hline Time post-AMPH, min & 10 & 20 & 30 & 40 \\
\hline$p$ value & 0.178 & 0.023 & 0.014 & 0.033 \\
\hline \multicolumn{5}{|l|}{ Planned contrast tests } \\
\hline Time post-AMPH, min & 10 & 20 & 30 & 40 \\
\hline$p$ Value, Control vs EB & NA & 0.037 & 0.083 & 0.233 \\
\hline$p$ Value, Control vs E2 & NA & 0.013 & 0.005 & 0.010 \\
\hline$U$ & 14.000 & 14.000 & 12.000 & 9.000 \\
\hline$p$ value & 0.034 & 0.034 & 0.021 & 0.009 \\
\hline \multicolumn{5}{|c|}{ Independent tests comparing rats treated with E2 and E2+MPEP in Experiment 3} \\
\hline Time post-AMPH, min & 10 & 20 & 30 & 40 \\
\hline$t$ value & $t_{(16)}=1.410$ & $t_{(16)}=2.790$ & $t_{(16)}=2.232$ & $t_{(16)}=1.993$ \\
\hline$p$ value & 0.178 & 0.013 & 0.040 & 0.064 \\
\hline
\end{tabular}

Values in bold indicate significant differences.

neously significantly enhanced AMPH-induced striatal DA release relative to the control group. Repeated-measures test showed there were a significant effect of treatment $\left(F_{(2,25)}=4.659, p=0.019\right)$ and a significant interaction effect of Treatment $\times$ Time $\left(F_{(6,75)}=3.640, p=0.003\right)$ in the DLS DA concentrations of the first four samples following AMPH injections. Planned post hoc comparison tests showed there were significant effects of E2 and EB compared with controls $(p=0.009$ and $p=0.048$, respectively). To better understand the time course on the differentiated elevation of peak DA levels among the three groups, one-way ANOVA tests (and a priori planned post hoc comparisons) were used to compare each of the four DA concentrations across conditions. Significant differences were found between the E2- and EB-treated rats and the control rats in the DA concentrations shortly after AMPH injections (Table 1).

Experiment 2: as shown in Figure 3, ICl significantly decreased EB-induced enhancement in the DA release in the DLS after an intraperitoneal injection of AMPH. A significant main effect of Treatment was found in the measured DA concentrations in the DLS $\left(F_{(1,15)}=7.360\right.$, $p=0.016)$. There was also a significant interaction be- tween Treatment $\times$ Time (repeated-measures: $F_{(3,45)}=$ 4.045, $p=0.010$ ). Mann-Whitney $U$ tests showed all the four samples collected after right after AMPH injections differed in DA concentrations for ICl-treated versus vehicle-treated rats (assumptions for parametric $t$ tests were not met, so nonparametric tests were used; Table 1).

Experiment 3: as shown in Figure 4, MPEP also significantly decreased EB-induced DA potentiation in the DLS post-AMPH treatment. There were a significant main effect of Treatment in the DA concentrations (repeatedmeasures: $F_{(1,16)}=5.895, p=0.027$ ) as well as a significant interaction of Treatment $\times$ Time in the DA concentrations (repeated-measures: $F_{(3,48)}=6.031, p=$ $0.001)$. Independent $t$ tests showed in nearly all samples after AMPH injections there were significant differences between rats treated with MPEP versus those with saline in DA concentrations (Table 1).

Experiment 4: as shown in Figure 5, MPEP or ICl did not influence DA release post-AMPH when E2 was not administered in OVX rats, unlike what was seen in Experiments 2 and 3 . The increase in DA concentrations postAMPH administration did not differ in MPEP or ICl-treated rats versus controls. There was a significant effect of Time

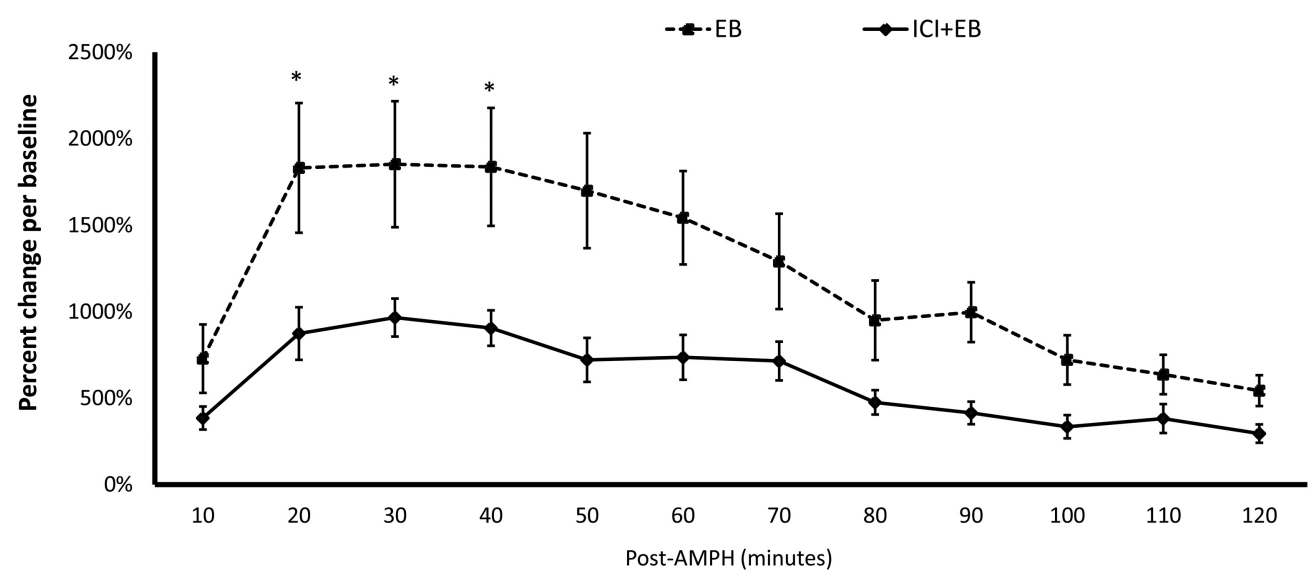

Figure $3 \mathrm{ICI}$ infused into the DLS reduces E2-induced DA potentiation following AMPH injections. *indicates a significant difference between rats treated with $\mathrm{ICl}$ and control rats. 


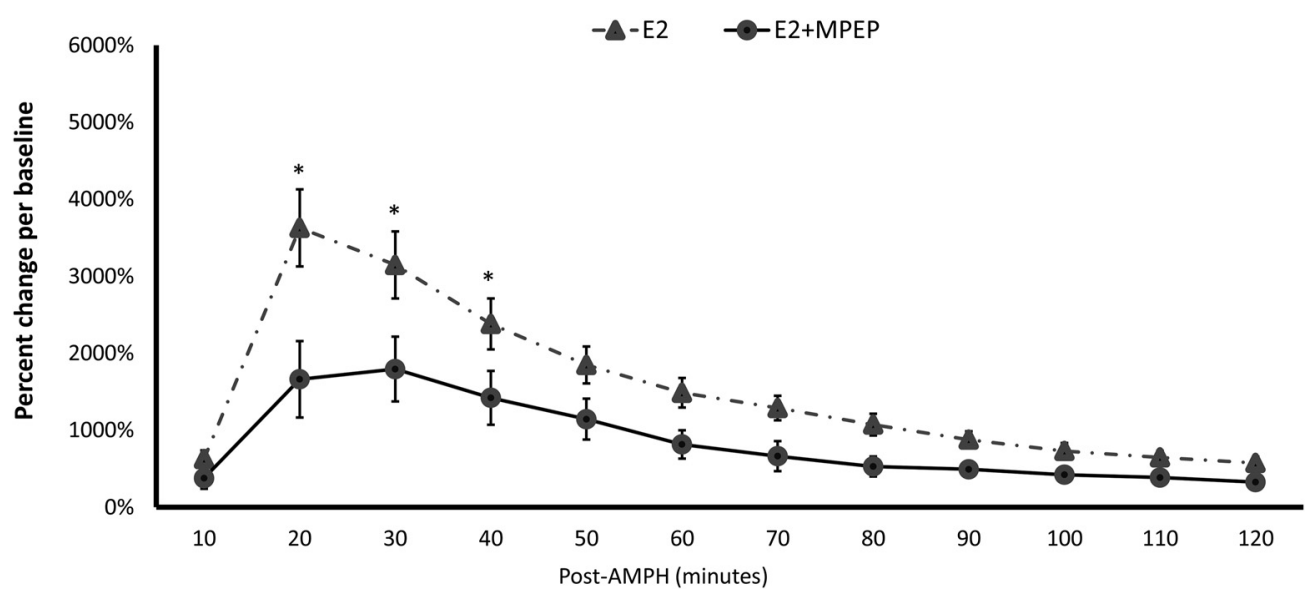

Figure 4 MPEP reduces E2-induced DA potentiation following AMPH injections. *indicates a significant difference between rats treated with MPEP and control rats.

$\left(F_{(3,45)}=16.300, p=2.598 \mathrm{E}-7\right)$, but there was no main effect of Treatment $\left(F_{(2,15)}=0.140, p=0.870\right)$ neither was there a significant interaction between Treatment and Time $\left(F_{(6,45)}=0.925, p=0.487\right)$.

Lastly, there was no effect of EB, E2, ICl, or MPEP on the DA release in the DLS prior to AMPH injections across all experiments (data not shown). This lack of difference indicates the above agents do not affect DA release independent of AMPH.

\section{Discussion}

The present study showed E2 enhances DA release in the DLS following AMPH administration. This enhancing effect of E2 is mediated by E2 receptors and mGlu5 receptors as blocking $\mathrm{E} 2$ receptors in the DLS by $\mathrm{ICl}$ or intraperitoneal injections of mGlu5 receptor antagonist MPEP inhibits the E2-induced DA elevation in DLS. We also showed that $\mathrm{ICl}$ and MPEP are not able to influence DA levels in the DLS when E2 is not administered in OVX rats.

There is mounting evidence that E2 has been implicated in addictive behavior. E2 enhances ethanol reward in female mice (Hilderbrand and Lasek, 2018). E2 is even found to increase choice of cocaine over food in male rats as observed in females (Bagley et al., 2017). Our data support the enhancing effect of E2 on reward and thus the notion that it exacerbates addictive behavior, as it increases dopamine levels in response to AMPH challenge. Interestingly, there is considerable evidence that estradiol reduces food intake in female rats (Yu et al., 2008; Butera et al., 2010; Santollo et al., 2010; Santollo and Daniels, 2015; Butler et al., 2018; but see Boswell et al., 2006; Butera et al., 2010). The mechanisms underlying the apparent differences in the roles of E2 in motivated behaviors are less well understood, but it could be that E2 acts in different brain regions to modulate different types of rewards (e.g., drug addiction vs food reward).

The ability of E2 in influencing addiction or reward may be because of its action in the midbrain dopamine reward system. Mice treated with E2 or ER $\beta$ agonists showed increased conditioned place preference for cocaine, whereas specific knockdown of the ER $\beta$ gene decreased cocaine conditioned place preference (Satta et al., 2018). Another study shows E2 acts on ventral tegmental area to increase the sensitivity of dopamine neurons to ethanol

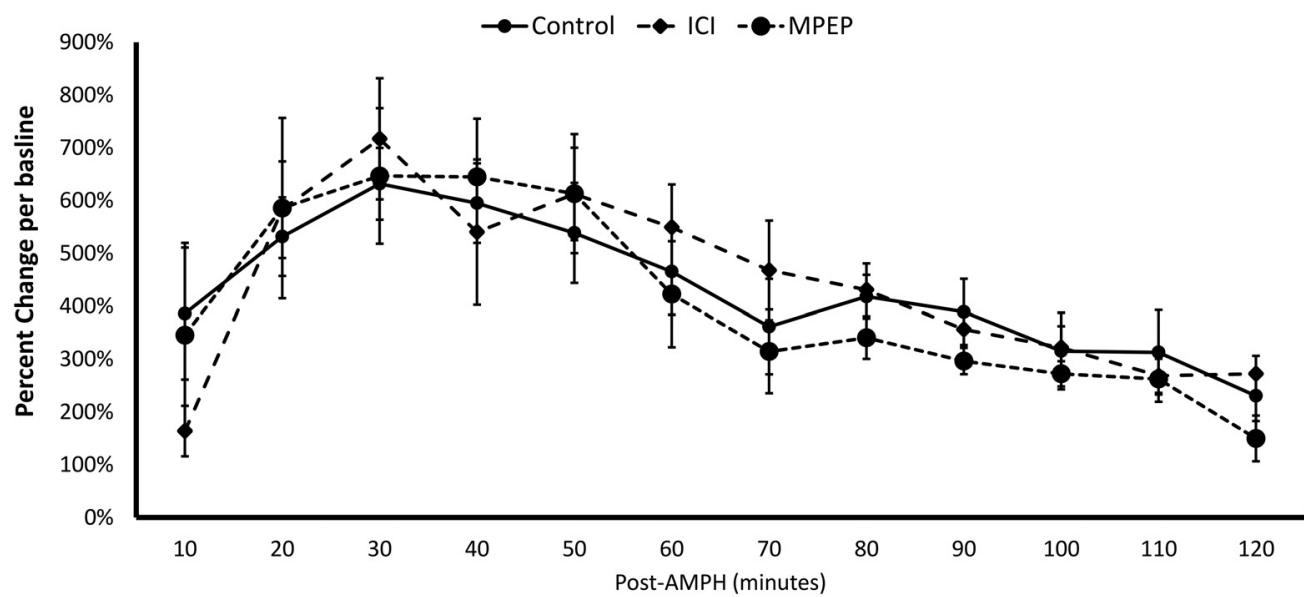

Figure 5 Neither ICI or MPEP influences DA release in the DLS when estradiol was not administered. These rats were ovariectomized and were not given EB injections or E2 infusions. 
(Vandegrift et al., 2017). E2 in the MPOA also increases DA release in the NAc in response to cocaine (Tobiansky et al., 2016). Our finding showed that E2 in the DLS potentiates dopamine release following AMPH injections. DLS plays a critical role in addictive behavior in both rodent and human studies. In humans, damage to dorsal striatum alleviates addiction to alcohol and nicotine (Muskens et al., 2012). In rodent studies, it has been suggested that dorsal medial striatum and NAc are crucial in the initial acquisition of the reward and then DLS and NAc begin to take over when the behavior becomes more addiction-like. Together, it is possible that E2 acts on different regions to convergently modulate addictive behavior.

Both ER $\alpha$ and ER $\beta$ have been reported in the E2 modulation of addictive behavior. The ER $\alpha$ agonist (propylpyrazole triol) and the ER $\beta$ agonist (diarylpropionitrile), independently increased choice on the high-reward tested in an operant chamber (Uban et al., 2012). These effects were most pronounced $24 \mathrm{~h}$ after administration suggesting genomic action of the receptors. Effects of E2 via its action on membrane receptors have been debated (Govind and Thampan, 2003) and there is increasing evidence showing rapid effects of E2 that are likely via non-genomic receptors (Revankar et al., 2005; Micevych et al., 2015; Paletta et al., 2018; Yoest et al., 2018). E2 is found to exert its effects via acting on G-protein-coupled estrogen receptors (GPER-1), as well as $\mathrm{ER} \alpha$ and $\operatorname{ER} \beta$ receptors, to rapidly facilitate short-term memory in female mice (Lymer et al., 2018). Our finding in the present study showed that E2 rapidly potentates dopamine release following AMPH treatment in the DLS. It will be important to further investigate the roles of each receptor type/location in these effects.

Several studies have shown that mGlu5 is involved in the effects of E2 in the regulation of behavior and physiology (Grove-Strawser et al., 2010; Peterson et al., 2015; Al-Sweidi et al., 2016). E2 is reported to mediate dendritic spine plasticity in the NAc through activation of mGlu5, evaluated via Dil labeling and confocal microscopy ( $\mathrm{Pe}-$ terson et al., 2015). The results of Peterson et al. (2015) suggest E2's role in mediating neuronal plasticity in the NAc via mGlu5 is important for E2's effect in drug addiction. Another study shows E2 facilitates cocaine selfadministration in OVX rats and mGlu5 activation is essential for this effect (Martinez et al., 2016). The study also demonstrates direct activation of mGlu5 is insufficient to mimic the effect of E2 in cocaine self-administration, suggesting that E2 receptors possibly need to be activated simultaneously to have the effect. Together, these findings are consistent with the results of the present study that both E2 receptors and mGlu5 s are necessary for E2's potentiation in DA release in DLS. It will be important to extend these results by examining the involvement of mGlu5 in other E2-mediated behaviors.

Although it is clear that both E2 receptors and mGlu5 are required for the estradiol evoked DA release from the DA terminals, our study does not show whether estradiol directly acts on or whether the two receptors are on the DA neurons. In fact, studies suggest estradiol activates E2 receptors coupled with mGlu5S on MSNs, which then modulates the release of GABA to influence DA terminals (Schultz et al., 2009). E2 receptors can be anchored to plasma membrane via caveolin protein, which then allow them to functionally couple with mGluRs (Yoest et al., 2018). The authors propose that E2 and mGlu receptors collaboratively act on MSNs in the DLS to modulate DA release from DA neuronal terminals. It is also possible that E2 acts on other interneurons (such as cholinergic neurons) to modulate DA release in the DLS, or influences glutamate release on cortical afferents.

Our data demonstrated marked increase of DA release in DLS following AMPH injections. This effect has been reported both in vivo and in vitro in our previous studies (Becker and Ramirez, 1981; Xiao and Becker, 1998; Becker and Rudick, 1999). Because of unknown vendor/ batch effects, different magnitudes of overall increase in DA concentrations following AMPH administration were observed in Experiments 1 and 3 (rats from Harlan Laboratories) than in Experiments 2 and 4 (rats from Charles River Laboratories).

\section{Conclusion}

The present study demonstrates that E2 directly potentiates the AMPH-induced increase in DA in the DLS. The effects of E2 are mediated by E2 receptors and can be blocked by an mGlu5 antagonist. These results provide important information on the neural mechanism through which E2 may contribute to sex differences in behaviors such as, but not limited to, addictive behavior. Our data also suggest that targeting mGlu receptors could be a potential treatment for E2 related disorders in female individuals.

\section{Reference}

Al-Sweidi S, Morissette M, Di Paolo T (2016) Estrogen receptors modulate striatal metabotropic receptor type 5 in intact and MPTP male mice model of Parkinson's disease. J Steroid Biochem Mol Biol 161:84-91. CrossRef Medline

Bagley JR, Adams J, Bozadjian RV, Bubalo L, Ploense KL, Kippin TE (2017) Estradiol increases choice of cocaine over food in male rats. Physiol Behav. Advance online publication. Retrieved from October 19, 2017. doi:10.1016/j.physbeh.2017.10.018.

Becker JB (2016) Sex differences in addiction. Dialogues Clin Neurosci 18:395-402. Medline

Becker JB, Ramirez VD (1981) Sex differences in the amphetamine stimulated release of catecholamines from rat striatal tissue in vitro. Brain Res 204:361-372. CrossRef Medline

Becker JB, Rudick CN (1999) Rapid effects of estrogen or progesterone on the amphetamine-induced increase in striatal dopamine are enhanced by estrogen priming: a microdialysis study. Pharmacol Biochem Behav 64:53-57. CrossRef Medline

Bobzean SA, DeNobrega AK, Perrotti LI (2014) Sex differences in the neurobiology of drug addiction. Exp Neurol 259:64-74. CrossRef Medline

Borrow AP, Handa RJ (2017) Estrogen receptors modulation of anxiety-like behavior. Vitam Horm 103:27-52. CrossRef Medline

Boswell KJ, Reid LD, Caffalette CA, Stitt KT, Klein LA, Lacroix AM, Reid ML (2006) Estradiol increases consumption of a chocolate cake mix in female rats. Pharmacol Biochem Behav 84:84-93. CrossRef Medline

Butera PC, Wojcik DM, Clough SJ (2010) Effects of estradiol on food intake and meal patterns for diets that differ in flavor and fat content. Physiol Behav 99:142-145. CrossRef Medline 
Butler MJ, Hildebrandt RP, Eckel LA (2018) Selective activation of estrogen receptors, ER $\alpha$ and GPER-1, rapidly decreases food intake in female rats. Horm Behav 103:54-61. CrossRef Medline

Ervin KS, Lymer JM, Matta R, Clipperton-Allen AE, Kavaliers M, Choleris E (2015) Estrogen involvement in social behavior in rodents: Rapid and long-term actions. Horm Behav 74:53-76. CrossRef Medline

Foster TC (2012) Role of estrogen receptor alpha and beta expression and signaling on cognitive function during aging. Hippocampus 22:656-669. CrossRef Medline

Govind AP, Thampan RV (2003) Membrane associated estrogen receptors and related proteins: localization at the plasma membrane and the endoplasmic reticulum. Mol Cell Biochem 253:233240. Medline

Grove-Strawser D, Boulware MI, Mermelstein PG (2010) Membrane estrogen receptors activate the metabotropic glutamate receptors mGluR5 and mGluR3 to bidirectionally regulate CREB phosphorylation in female rat striatal neurons. Neuroscience 170:10451055. CrossRef Medline

Hilderbrand ER, Lasek AW (2018) Estradiol enhances ethanol reward in female mice through activation of $\mathrm{ER} \alpha$ and $\mathrm{ER} \beta$. Horm Behav 98:159-164. CrossRef Medline

$\mathrm{Hu}$ M, Becker JB (2003) Effects of sex and estrogen on behavioral sensitization to cocaine in rats. J Neurosci 23:693-699. Medline

Hu M, Becker JB (2008) Acquisition of cocaine self-administration in ovariectomized female rats: effect of estradiol dose or chronic estradiol administration. Drug Alcohol Depend 94:56-62. CrossRef Medline

Long N, Serey C, Sinchak K (2014) $17 \beta$-estradiol rapidly facilitates lordosis through $\mathrm{G}$ protein-coupled estrogen receptor 1 (GPER) via deactivation of medial preoptic nucleus $\mu$-opioid receptors in estradiol primed female rats. Horm Behav 66:663-666. CrossRef Medline

Lymer JM, Sheppard PAS, Kuun T, Blackman A, Jani N, Mahbub S, Choleris E (2018) Estrogens and their receptors in the medial amygdala rapidly facilitate social recognition in female mice. Psychoneuroendocrinology 89:30-38. CrossRef Medline

Martinez LA, Gross KS, Himmler BT, Emmitt NL, Peterson BM, Zlebnik NE, Foster Olive M, Carroll ME, Meisel RL, Mermelstein PG (2016) Estradiol facilitation of cocaine self-administration in female rats requires activation of mGluR5. eNeuro 3:ENEURO.014016.2016. CrossRef Medline

Martinez LA, Peterson BM, Meisel RL, Mermelstein PG (2014) Estradiol facilitation of cocaine-induced locomotor sensitization in female rats requires activation of mGluR5. Behav Brain Res 271:3942. CrossRef Medline

Mermelstein PG, Becker JB, Surmeier DJ (1996) Estradiol reduces calcium currents in rat neostriatal neurons via a membrane receptor. J Neurosci 16:595-604. CrossRef Medline

Micevych PE, Wong AM, Mittelman-Smith MA (2015) Estradiol membrane-initiated signaling and female reproduction. Compr Physiol 5:1211-1222. CrossRef
Muskens JB, Schellekens AF, de Leeuw FE, Tendolkar I, Hepark S (2012) Damage in the dorsal striatum alleviates addictive behavior. Gen Hosp Psychiatry 34:702.e709-702.e711. CrossRef Medline

Paletta P, Sheppard PAS, Matta R, Ervin KSJ, Choleris E (2018) Rapid effects of estrogens on short-term memory: possible mechanisms. Horm Behav 104:88-99. CrossRef

Peterson B, Mermelstein P, Meisel R (2015) Estradiol mediates dendritic spine plasticity in the nucleus accumbens core through activation of mGluR5. Brain Struct Funct 220:2415-2422. CrossRef Medline

Revankar CM, Cimino DF, Sklar LA, Arterburn JB, Prossnitz ER (2005) A transmembrane intracellular estrogen receptor mediates rapid cell signaling. Science 307:1625-1630. CrossRef Medline

Santollo J, Daniels D (2015) Activation of G protein-coupled estrogen receptor 1 (GPER-1) decreases fluid intake in female rats. Horm Behav 73:39-46. CrossRef Medline

Santollo J, Katzenellenbogen BS, Katzenellenbogen JA, Eckel LA (2010) Activation of ER $\alpha$ is necessary for estradiol's anorexigenic effect in female rats. Horm Behav 58:872-877. CrossRef Medline

Satta R, Certa B, He D, Lasek AW (2018) Estrogen receptor $\beta$ in the nucleus accumbens regulates the rewarding properties of cocaine in female mice. Int J Neuropsychopharmacol 21:382-392. CrossRef Medline

Schultz KN, von Esenwein SA, Hu M, Bennett AL, Kennedy RT, Musatov S, Toran-Allerand CD, Kaplitt MG, Young LJ, Becker JB (2009) Viral vector-mediated overexpression of estrogen receptor- $\alpha$ in striatum enhances the estradiol-induced motor activity in female rats and estradiol-modulated GABA release. J Neurosci 29:1897-1903. CrossRef Medline

Song Z, Kalyani M, Becker JB (2018) Sex differences in motivated behaviors in animal models. Curr Opin Behav Sci 23:98-102. CrossRef Medline

Tobiansky DJ, Will RG, Lominac KD, Turner JM, Hattori T, Krishnan K, Martz JR, Nutsch VL, Dominguez JM (2016) Estradiol in the preoptic area regulates the dopaminergic response to cocaine in the nucleus accumbens. Neuropsychopharmacology 41:18971906. CrossRef Medline

Uban KA, Rummel J, Floresco SB, Galea LA (2012) Estradiol modulates effort-based decision making in female rats. Neuropsychopharmacology 37:390-401. CrossRef Medline

Vandegrift BJ, You C, Satta R, Brodie MS, Lasek AW (2017) Estradiol increases the sensitivity of ventral tegmental area dopamine neurons to dopamine and ethanol. PLoS One 12:e0187698. CrossRef Medline

Xiao L, Becker JB (1998) Effects of estrogen agonists on amphetamine-stimulated striatal dopamine release. Synapse 29: 379-391. CrossRef Medline

Yoest KE, Quigley JA, Becker JB (2018) Rapid effects of ovarian hormones in dorsal striatum and nucleus accumbens. Horm Behav 104:119-129. CrossRef

Yu Z, Geary N, Corwin RL (2008) Ovarian hormones inhibit fat intake under binge-type conditions in ovariectomized rats. Physiol Behav 95:501-507. CrossRef Medline 